\title{
VOORWOORD \\ DEUR DIE VOORSITTER VAN DIE KOMMISSIE VAN DIE ALGEMENE KERKVERGADERING VAN DIE NEDERDUITSCH HERVORMDE KERK VAN AFRIKA
}

Die outeur, professor J.P. Oberholzer, kies om sy oorsig oor die honderdjarige bestaan van die Kuratorium vir Teologiese opleiding as ' $n$ kroniek te bestempel. 'n Kroniek is 'n verhaal van gedenkwaardige gebeurtenisse wat chronologies gerangskik word (vergelyk die Verklarende Handwoordeboek van die Afrikaanse Taal). In hierdie kroniek is die belangrike gebeurtenisse in die verloop van honderd jaar inderdaad aan die hand van notules en dokumente noukeurig nagevors en chronologies neergepen.

Wanneer daar by wyse van ' $n$ kroniek na die verlede gekyk word, is dit moeilik om selektief te werk te gaan. Die feite dring hulle in die historiese dokumente aan die geskiedskrywer op. Of ' $n$ mens daarvan hou of nie, dit is wat gebeur het en die gebeure moet weergegee word. Geskiedenisse word dikwels subjektief en selektief geskryf as ' $n$ poging om die hede

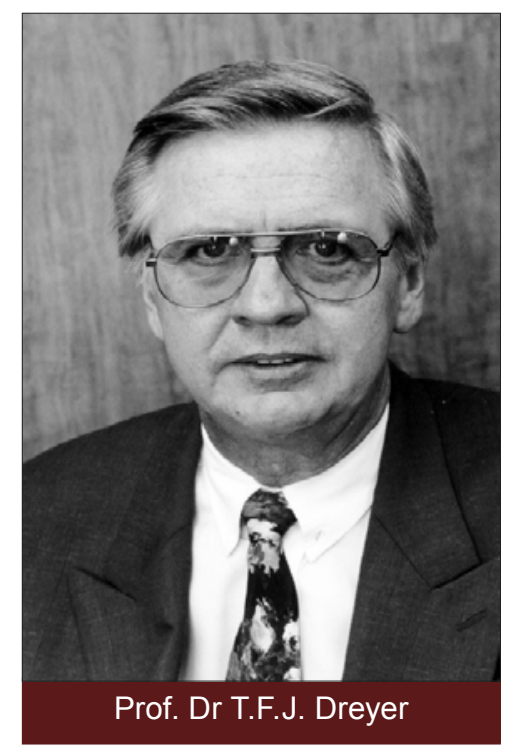

Kerk en Afdeling B van die Nederduitse Gereformeerde Kerk. Die kringloop is voltooi in 2000 met weer 'n veelkerklike fakulteit.

Hierdie kroniek is ook ' $\mathrm{n}$ verhaal van gelowige lidmate, ouderlinge, predikante en dosente. Dit getuig van hulle liefde vir die kerk, offerbereidheid en die oortuigings waarvoor hulle bereid was om te werk, te dien en te stry. Die Nederduitsch Hervormde Kerk was geseënd met begaafde teoloë. Alhoewel die Hervormde Kerk klein in getalle is, is teoloë van formaat gelewer wat selfs internasionaal presteer het. Alhoewel daar soms hewig oor teologiese aksente verskil is, wys die historiese dokumente uit dat studente met lof getuig van die vormende invloed wat dosente op hulle lewe en geloof gehad het. te legitimeer. Hierdie kroniek stel egter die gebeure self aan die woord en ontbloot onderliggende motiewe wat ons dalk liewer sou wou verswyg. Dit vertel 'n verhaal van mense wat kinders van hulle tyd was en hulleself daarom moeilik kon losmak van die eietydse politieke en teologiese onderstrominge. Dit laat iets deurskemer van ideale en persoonlike ambisies wat gelei het tot groepvorming en die manipulering van vergaderings.

Elke mens se lewensverhaal het skadukolle. As ' $n$ mens dit ontken en vermy, vind daar geen groei en verandering plaas nie. Wanneer ' $n$ mens egter bereid is om ook die skadukolle oop te vlek en in die oë te kyk, hoe pynlik ookal, is dit dikwels die stimulus vir 'n positiewe leerervaring en groei. Die kroniek kan ons as Kerk sensiteer om in die toekoms nie weer dieselfde foute te maak nie.

Wanner ' $n$ kroniek gelees word, is dit gewoonlik die negatiewe en skokkende gebeure wat die eerste, en soms ook blywende, indrukke skep. Om die negatiewe so te laat oorheers, sou egter eensydig wees en nie reg laat geskied aan honderd jaar se pogings om, dikwels onder baie moeilike omstandighede, vir die Hervormde Kerk predikante op te lei nie. Die kroniek vertel ook die verhaal van die Hervormde Kerk wat kort na die vernedering, verarming en swaarkry van die Tweede Vryheidsoorlog, met geloof en waagmoed die toekoms aangedurf het. Die ideaal van ' $n$ eie predikanteopleiding en om nie meer langer afhanklik te wees van predikante uit Nederland of uit ander kerke nie, was ook deurweek van die oortuiging dat dit nie 'n tweederangse kweekskoolopleiding moet wees nie. 'n Deeglike, wetenskaplike universitêre opleiding was ononderhandelbaar. Die Kuratorium is reeds in 1909 in die lewe geroep, nog voordat die eie teologiese opleiding bestaan het. Dit was juis die Kuratorium se taak om aan die ideaal van 'n eie opleiding gestalte te gee.

Aan die begin van die teologiese opleiding was die fakulteit veelkerklik. Dit is pas later uitgebou tot ' $n$ selfstandige teologiese fakulteit vir die Hervormde Kerk. Mettertyd het twee afsonderlike afdelings ontstaan, Afdeling A van die Nederduitsch Hervormde
Die Nederduitsch Hervormde Kerk staan nie los van die tydsgees en die nuwe teologiese denke wat daarmee gepaard gaan nie. Die Hervormde Kerk het nog altyd ruimte gemaak vir verskillende teologiese aksente en debatvoering dit is immers die kenmerk van teologiese opleiding aan 'n universiteit. Dit alles is inherent deel van die honderd jaar se gekiedenis en kom telkens in die kroniek na vore. Ernstige konfrontasies en selfs ' $n$ tugsaak maak deel uit van vloei en eb van teologiese getye. Deur dit alles heen wil die Hervormde Kerk teologies daaraan uitdrukking geen om telkens weer opnuut te luister na wat ons in die Woord van God hoor. Juis die bereidheid om opnuut te 'luister', is noodsaak in 'n wetenskaplik-teologiese opleiding.

Dit is makliker om oor die eerste vyftig jaar van die geskiedenis te praat en te oordeel, want ons was nie self deel daarvan nie. Die laaste vyftig jaar se geskiedenis laat die wat in ' $n$ mindere of meerdere mate daaraan deel gehad het, egter dikwels met ' $n$ gevoel van ongemak. Dit help nie om die ongemak te ontken nie. Dalk kan hierdie kroniek daartoe bydra dat ons leer uit die foute en vorentoe met groter omsigtigheid sal optree. Dalk kan dit ons, hoe moeilik ookal, help om los te kom van eie voorkeure en in die toekoms oor die kerk en die teologie te dink en te praat.

Die kroniek is ' $\mathrm{n}$ waardevolle stuk navorsing wat professor Oberholzer noukeurig en met groot toewyding opgeteken het. Dit kan ' $n$ belangrike bron vir toekomste navorsing word. Hierdie stuk geskiedskrywing bied insigte aan die predikante en teoloë van die Hervormde Kerk en veral aan die wat verkies word tot lede van die Kuratorium vir Teologiese Opleiding. Uitdagings, vrae, probleme, teologiese onderstromings en die spanning tussen die Kerk en die teologiese opleiding is nie uniek aan ons tyd nie. Hierdie kroniek toon dat dit nog altyd deel was van die Kerk, die Kuratorium en die teologiese opleiding, en seker altyd sal wees. Uit die geskiedenis kan waardevolle lesse geleer word wat ons kan help om op 'n gebalanseerde en verantwoordelike wyse om te gaan met die problematiek van ons tyd.

Sitasie: Dreyer T.F.J., 2010, 'Voorwoord deur die voorsitter van die Kommissie van die Algemene Kerkvergadering van die Nederduitsch Hervormde Kerk van Afrika', in 'Honderd Jaar Kerk en Teologiese Opleiding: 'n Kroniek van die Hervormde Kerk', HTS Teologiese Studies/Theological Studies, suppl. 9, 66(3), Art. \#943, 1 page. DOI: $10.4102 /$ hts.v66i3.943 